\title{
Perceptions and Aspirations: $A$ Case Study of Young People in Ghana's Cocoa Sector
}

\author{
Nana Akua Anyidoho, Jennifer Leavy and Kwadwo Asenso-Okyere
}

\begin{abstract}
This article considers the question of young people's aspirations in agriculture in light of the renewed interest in the agricultural sector as a viable basis for development in sub-Saharan Africa (SSA), and the perception that young people's involvement is important for the success of this project. Life choices and outcomes are affected in part by aspirations. The nature and formation of young people's aspirations therefore have direct implications for emerging visions and future models of agriculture to the extent that young people's aspirations inform the decisions they make in relation to agriculture. The article takes issue with essentialising policy narratives about rural youth in agricultural areas that obscure the diversity that exists within that group. We need to investigate such diversity and its significance for young people's aspirations. Using the case of the cocoa sub-sector in Ghana, we analyse how the differences in young people's backgrounds and experiences with cocoa influences their expectations of the role of cocoa farming in their future.
\end{abstract}

\begin{abstract}
1 Introduction
Recent research presents aspiration formation as a dynamic process, developing within and influenced by the context in which a person lives. This context encompasses personal beliefs, societal expectations, and structural opportunities and constraints. The literature presents two main ways of conceptualising aspirations. The first is of aspirations as embodying some component of reality; that is, what people expect to achieve (see MacBrayne 1987). Second are aspirations as 'hopes and dreams' which are not necessarily rooted in reality (e.g. Morrison Gutman and Akerman 2008; Quaglia and Cobb 1996. See Leavy and Smith 2010 for a review). Our study took a broad view of aspirations; we asked young people in rural Ghana what they wanted to do in the future and in what ways cocoa farming might feature in their plans. Some plans were immediate and within reach (e.g. farming on family land to make money to learn a trade), while others were long-term and perhaps less achievable for some of the young people in our sample (e.g. obtaining a university degree and subsequently securing a white-collar job).
\end{abstract}

Our study helps to fill the gap in knowledge on young people in Africa outside certain narrow areas (see Sumberg et al., this IDS Bulletin). Specifically, there is a dearth of recent, empirical studies on their aspirations, and even less for young people in rural areas (Leavy and Smith 2010). Despite this lack of information, the notion has developed that young people are not interested in engaging in agriculture (see Anyidoho et al. 2011 for a review of policy narratives on young people and agriculture). Admittedly, there is some support for this supposition. With reference to Tanzania, Juma (2007: 2) finds a career in agriculture lacks appeal for many young people as it is framed very much as farming and seen to be a dirty activity, and thus 'an employer of the last resort', a finding that is echoed by Tadele and Ayalew Gella (this IDS Bulletin) using data from Ethiopia.

Kritzinger's (2002) study of teenage girls working as hired labour on fruit farms turned up similarly negative views of farming. These relate not only to low wages but also to the social challenges of living and working on the farm, including alcohol abuse; lack of privacy, boredom and social isolation; and the low status attributed to farm 
children compared to those living in towns and villages. Low status in Perry's (2009) study in Senegal was also a key consideration in young men's livelihoods preferences, with different types of agricultural activity associated with varying degrees of economic benefit and prestige. Put together, these studies do not provide sufficient empirical evidence for the claim that young people in sub-Saharan Africa (SSA) as a region are choosing to reject agriculture wholesale. The studies we have cited tend to ask about young people's perceptions of agriculture (read: farming) as a long-term employment or livelihood activity. Are there other constructions of agriculture that may have more value for young people under varying circumstances? Does the construction of agriculture change over the life course and with a reconfiguration of the 'opportunity space' (see Sumberg et al., this IDS Bulletin)?

Finally, do we expect that differences in young people's education, socioeconomic situation of their family, and experience with agriculture may affect aspirations? These are questions that this article attempts to address. In doing so, we reveal a mismatch between national policies that reflect government strategies for development, and the expectations and strategies of young people. We argue that policy has to grapple with these contradictions if it is to be at all effective in both promoting young people's personal development and societal (national) development through agriculture.

Agriculture has made a comeback onto the agendas of policymakers, donors and governments after two decades of relative neglect in terms of government expenditure and development assistance. The new agenda for agriculture is to revitalise the sector and increase the share of agro-industry in the economy, so that agriculture is the 'engine' of economic growth and the basis for industrialisation. Despite these expectations, productivity and sustainability has been a source of concern for policymakers. One commonly cited reason is labour shortage as a result of an ageing rural population in SSA, where most agricultural production takes place (Stloukal 2000; see also Mba 2004). This fact is then folded into a popular policy narrative that states that young people must be mobilised to engage in agriculture. Not only will they provide more labour but crucially they will infuse agriculture with innovation and entrepreneurial impetus that will realise the transformation of the sector (Anyidoho et al. 2011). The obstacle to this vision, according to this policy narrative, is young people's disinterest in the agricultural sector and their preference for leaving agricultural areas to seek alternatives to on-farm agricultural work (ibid.). The question then becomes how to attract young people to agriculture.

This question is even more compelling because it dovetails into another critical policy issue, namely youth unemployment and underemployment. Worldwide, the youth unemployment rate is higher than that for adults and, with the economic crisis, has increased from 11.9 per cent in 2007 to 13 per cent in 2009 (ILO 2010). Youth employment was a major theme in the World Bank's 2007 report (World Bank 2006), was underscored in the UN declaration of 2010-11 as the International Year of the Youth, and features in the Millennium Development Goals. Creating employment for young people, therefore, is another strand of the policy narrative around young people and agriculture (see Anyidoho et al. 2011) since the agricultural sector is the largest employer for African countries.

The policy narrative that has developed thus encompasses both these issues of youth employment and the sustainability and growth of agriculture: agriculture is in danger because young people do not want to be involved in it; African countries therefore need to develop policies to motivate young people to go into agriculture to sustain the sector and, at the same time, solve the problem of youth employment. This article is motivated by the problems that this narrative presents. First, it is important to point out that though the narrative is ostensibly about 'agriculture', the way the problem is framed (young people are moving away from rural, agricultural areas) and the solutions offered (get young people back to rural, agricultural areas) suggests that what is really being talked about is young people's involvement in rural farming. What is ignored then is the range of off-farm manufacturing and other entrepreneurial activities that make up the agricultural sector. In other words, the narrative is not really about young people's participation in the agriculture sector writ large but rather about young people as farmers. Second, the narrative 
puts stress on labour shortage and lack of innovation as the source of the problem of low productivity, and suggests that both problems will be solved with young people's involvement. This simplistic framing of the problem discourages an examination of the confluence of factors that may constrain productivity, including lack of investment in inputs, infrastructure and markets; existing land tenure systems; and the organisation of production and distribution at household level. Finally, the axiom of young people's lack of interest in, and even disdain for, agriculture has little empirical basis, as we have mentioned, since there are few studies into young people's perceptions of, and aspirations towards, agriculture.

In this article, we use Ghana as a case study to further examine this dominant framing of the young people-agriculture nexus. We focus on the cocoa sub-sector because of its importance to Ghana's agricultural sector and to national development. In doing this, we keep in mind the ways in which the cocoa sector can be considered a microcosm of the wider agriculture sector but is, at the same time, peculiar in its role in the Ghanaian economy and society relative to other agricultural crops.

\section{The cocoa sub-sector in Ghana}

Ghana's policy documents echo global arguments about agriculture, sustainability and young people's role. Policy documents acknowledge the importance of agriculture for social and economic transformation (see NDPC 2005, 2010).

Agriculture has the biggest share of GDP at 39 per cent and contributes to employment, livelihoods and poverty reduction (NDPC 2010). At the same time, low productivity and low income, coupled with a generally unappealing rural environment, are thought to make agriculture unattractive to young people (MMYE n.d.; MoFA 2007; NDPC 2010). Some policy documents explicitly state that the lack of appeal of agriculture repels young people out of rural areas, leaving an ageing and less educated rural population to sustain agriculture production ${ }^{1}$ (e.g. MoFA 2007: 3). Further, the need to attract young people to agricultural production in Ghana is tied to the need to provide young people with jobs (see NDPC 2010; MMYE n.d.), to secure their future, reduce poverty levels and boost development (see MoFA 2007; MYS 2010).
Thus, initiatives such as the Programme for Youth Employment and Accelerated Agricultural Production and the Youth in Agriculture Programme make a clear connection between the policy issues of agricultural sustainability and productivity and employment for young people (ibid.).

A discussion of Ghana's agricultural sector must necessarily reference cocoa. Cocoa revenue financed dramatic expansions in physical infrastructure and social services under the colonial and immediate post-independence government and, despite attempts to diversify into other crops, cocoa remains largely responsible for growth in the economy as a whole (NDPC 2010). ${ }^{2}$ Further, cocoa revenue has contributed to poverty reduction in the country; it is indicative that poverty rates have fallen in the past decade in the cocoa-producing forest regions, while poverty has increased in the fishing and food crop-producing coastal and savannah areas (ibid.).

Cocoa has not just been an economic force but has had social impact as well. Cocoa production in Ghana has influenced and been influenced by social institutions. It has affected land tenure systems and, by virtue of their intimate relation to land, the dynamics of traditional authority systems and kinship relations, ${ }^{3}$ both of which have been disrupted and reshaped in the struggle for access to and control of farmlands (Mikell 1989). Kinship again interacts with cocoa as the basis for organisation of production (ibid.), consistent with the fact that the family is the basic economic unit in Ghanaian society (Nukunya 1992). This has meant that labour for cocoa production has conventionally been supplied by the family, with additional labour from the labour market through sharecropping arrangements, or through nnoboa ${ }^{4}$ Furthermore, cocoa income created a class of rich farmers who were able to access formal education for their children, both locally and overseas (ibid.) and at different points in history, cocoa farmers have been among the wealthiest. Cocoa production has also been implicated in migration patterns, especially in the movement of labour from the north to southern cocoa-producing areas (see Asuming-Brempong et al. 2007; Hashim 2005; Hill 1963).

Given the centrality of cocoa to the agricultural sector and to national development, it is not 
surprising that its sustainability would be a concern, especially with the renewed importance of agriculture to development. Even though the volume of cocoa production has risen steadily in the past decade, the national average yield of cocoa farms in 2007 was $350-400 \mathrm{~kg}$ per hectare, compared with 800-1000kg per hectare in neighbouring Côte d'Ivoire (Barrientos et al. 2007). One explanation often given is that cocoa production in Ghana is mainly carried out by smallholders and is labour-intensive. In the past, labour was supplied by the farmer and his/her family. However, with migration and increased school enrolment, it has become difficult to find labour for cocoa farming activities. This situation has bid up the farm labour wage, which is now often higher than the minimum wage (Barrientos et al. 2007). ${ }^{5}$ One study found that income from cocoa production accounted for twothirds of household income, but that this income was only US $\$ 0.42$ per capita per day (ibid.). Low productivity, lack of innovation and low incomes are other reasons given in Ghana's policy documents as to why young people do not want to enter agriculture (Anyidoho et al. 2011). Reasons for the low yields included the 'decreasing fertility of land, the age (and low yield) of cocoa trees, the expense of inputs, and the waning attention of the government and Ministry of Agriculture to the circumstances of cocoa farming and cocoa farmers' (Barrientos et al. 2007: 64). Thus, there are many parts to the problem of low productivity and sustainability in the cocoa sector. Do policies looking at the young people-agriculture nexus recognise these complexities in terms of the framing of the problem and the proposed solutions? Do young people? In other words, to what extent do young people's perceptions of and aspirations in agriculture match up to the perspectives and approaches in policy documents, and are both sets of perspectives in touch with the reality of the agriculture sector?

\section{The study}

This article is based on data obtained from fieldwork conducted in 12 cocoa farming communities in cocoa districts of Ghana in $2006 .{ }^{6}$ The districts were purposively selected from Western, Ashanti and Eastern regions, stratified as high, medium and low cocoa-producing areas, respectively, using production data from the Ghana Cocoa Board (Table 1).

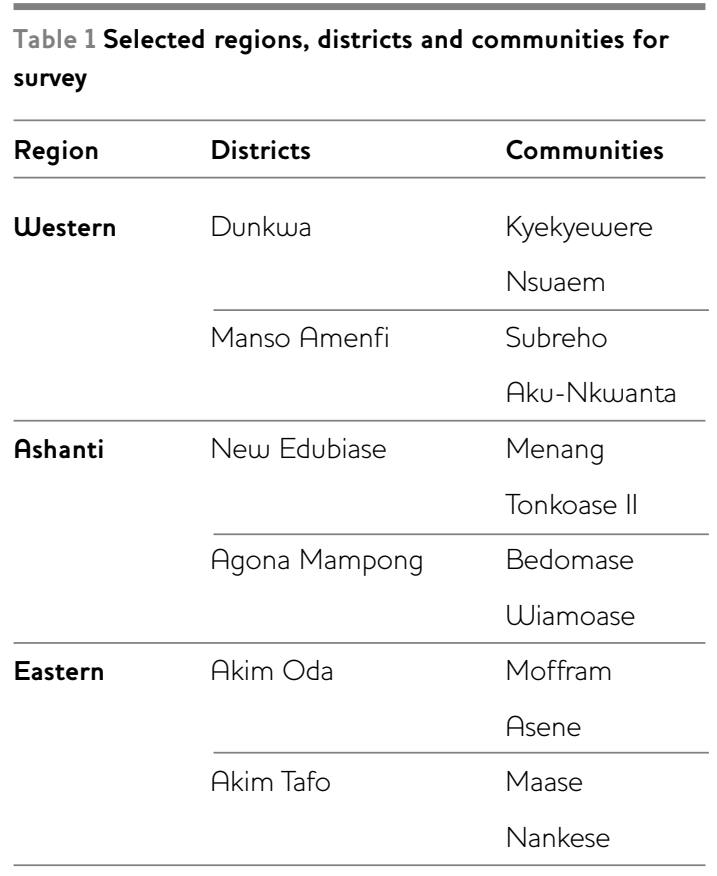

Source Ghana Cocoa Board.

Data were obtained from life history interviews and 12 focus group discussions (FGDs) with 107 young people ( 45 females and 62 males) aged 16-26 years. The focus group discussions covered perceptions and aspirations towards cocoa farming, and young people's opinions about the gap between the current situation of cocoa farmers/farming and the circumstances under which they would consider cocoa farming as a primary or secondary occupation.

\subsection{Diversity of young people in cocoa farming areas}

The young people encountered through the study were selected to be diverse in terms of residence, education, involvement in cocoa farming, and experiences of life outside of their community. The research sites differed in availability and quality of economic infrastructure such as roads, amenities such as electricity and potable water, and social infrastructure such as schools and clinics, which are important indicators of quality of life and may be a consideration in young people's decisions about settling in or remaining in these areas.

Differences in levels of education are important for aspiration formation because of the relation of educational attainment to perceived and actual opportunities. Roughly half of the participants were current students or recent 
graduates of junior (JHS) or senior high school (SHS). The proportion of students in the focus groups was higher in the bigger towns than in the small villages, presumably because these towns had more schools and also because the relatively higher income levels allowed parents to send their children to school. The remainder had primary or no formal education at all.

Most young people interviewed had also experienced life outside of their immediate surroundings, which suggests exposure to different places, peoples, and sub-societies of Ghana, with differences in the nature and degree of exposure across the sample. Those young people who had migrated independently or with family had various migration patterns - rural to rural, rural to urban, or urban to rural. Even those born locally experienced some mobility, to the nearest town, or to other districts and regions for school or work. In one town in particular, Asene in the Eastern Region, we came across young people who had travelled to Nigeria to work. These experiences are important because of the social nature of aspirations; that is, aspirations tend to be formed through interaction with other people (Morrison Gutman and Akerman 2008; Whitehead et al. 2007; Del Franco 2006).

Finally, most of the young people interviewed had in common first-hand experience of farming, though depth of experience varied across the group. Some were full-time farmers and others worked on farms part-time. Even if not currently involved in farming, all the young people reported helping their parents on farms when they were younger. Their farming experience was mainly in cocoa and food crops.

We again note that all these differences are important not merely for providing a profile of the young people in the cocoa-growing areas, but also correspond to young people's aspirations, as we discuss in the next section.

\section{Categories of aspiration}

Analysis of the focus group discussions and the life history interviews reveal a hierarchy of aspirations concerning young people's occupational aspirations. Significantly, the different categories of aspiration roughly correspond with particular profiles of young people. Young people's prior experience and current engagement with farming, and their current and expected educational attainment, were most implicated in the content of their aspirations.

Below, in ascending order of preference, are the categories of occupational aspirations derived from analysis of interviews and focus group discussions with the young people in our research sites:

- farming on own farm as primary occupation;

- farming as a means of capital accumulation towards non-farm primary occupation;

- formal work as primary occupation, with no direct engagement with farming.

In this section, we describe the profiles of young people holding each of these aspirations. There are two related dimensions that can be used to categorise young people. One is educational attainment: there was an observed distinction between young people with no formal schooling or with minimal (that is, lower primary) education, and young people with higher primary and high school education. The second dimension is current occupation or employment status which relates primarily to whether the young person was a full-time student or was employed in farming in some form.

\subsection{Farming as a primary occupation}

Previous studies record significant migration of young people from rural areas of Ghana.

Contrary to popular perception that young migrants invariably head for the cities, many end up working in agriculture, notably in cocoagrowing areas (see Hashim 2005; Whitehead et al. 2007). For these young people, leaving home to farm elsewhere holds prospects of greater cash income and other resources than they might have in their places of origin. A few such young people were in our sample, exclusively in the cocoa farming settlements of Subreho and AkuNkwanta/Hiamanka which has predominantly migrant families. Each of these young people aspired to farm under better terms. Osei and his wife, Mamuna, had migrated to Subreho from northern Ghana. Mamuna's story is interesting because her own aspirations in relation to cocoa farming intersect with those of her husband and brother, young migrants hoping to progress from caretaking arrangements, to sharecropping (farming on land belonging to another person 
Mamuna's (age 21) parents migrated from Bolgatanga in the north of Ghana to southern Ghana, to work as caretakers on a rice farm. Mamuna's mother returned home after the death of her husband but Mamuna remained hoping to finish school, ending up working on a relative's rice farm. After a failed arranged marriage, Mamuna returned to live with an aunt who enrolled her as an apprentice to a seamstress. She soon met Osei, a young man from her hometown who told her he had prospects in cocoa farming and was headed to Subreho to act as caretaker of a farm, and hopefully to establish a farm of his own. He promised he would give her some of his earnings so she could continue her apprenticeship training. They were married and immediately moved to Subreho to help Osei's older brother with his contract as a caretaker, hoping that the farm-owning family would soon give him a contract of his own. However, according to Mamuna, Osei was not serious about farming and preferred to work as a casual day labourer for quick money. Although Mamuna wanted to help Osei to work towards buying their own cocoa farm, that did not seem likely and she was thinking of going to the Western Region to live with her older brother who, having started out as a labourer on a cocoa farm, now owned a six-acre cocoa farm, and was caretaker for another 10 acres of cocoa farmland.

and sharing the proceeds or the farm), to ultimately owning a farm on leased or purchased land, with each stage implying increased control over farming activities and better income.

\subsection{Farming as a means of capital accumulation towards non-farm primary occupation}

More than half of the young people interviewed aspired to learn a trade in auto-mechanics, carpentry, or electrical works, typically in a larger town. Most had some level of formal education, in contrast with those who aspired to be farmers who had very little or no formal education. This group is represented by Kwaku, Owusu, Alex and Mosi in Aku-Nkwanta in the Western Region, who all saw their current cocoa farming activities (Kwaku, Owusu and Alex on family farms; Mosi as a caretaker) as a means to acquire the funds to allow them to enter a trade at a future date.
Since all four young men profiled aspired to undertake a trade, it would be easy to miss the subtle differences among them. Kwaku, Owusu and Alex had some education which seemed to have expanded their life expectations. Kwaku and Owusu were further influenced by the fact that they had spent time in bigger cities, which would have a similar effect of increasing their perceived range of options. While the three acknowledged their reliance on cocoa in order to achieve their ambitions, they were explicit that cocoa farming was a stop-gap measure; a means of earning income so they could move on to other work (see Sumberg and Okali 2006). Cocoa farming was an unwanted but necessary step back in order to go forward. In other words, they would have preferred to move on to their aspiration of learning a trade without having to engage in cocoa farming at all because the

Kwaku (age 18) and Owusu (age 21) had gone to school outside of the village, and had moved back to take over their fathers' farms. Neither of their families lived in the village, although both had spent a part of their childhood in Aku-Nkwanta as part of a migrant farming family. They both described the challenge of resuscitating farms that had been neglected. Both were hoping to stay in the village only long enough (perhaps three years) to earn enough money to go into a trade. They would leave the farm in the hands of a caretaker, and occasionally make supervising visits.

Alex (age 21) had lived in Aku-Nkwanta with his family all his life, but he was also hoping that, with the money he earned helping his father on the farm, he could move to Kumasi to enter into a trade.

Mosi (age 24) who has had no schooling was born to a migrant cocoa farmer in Aku-Nkwanta, and had spent his childhood and teenage years working on different farms as a labourer. He had progressed to being a caretaker. He planned to work for another four years, and make enough money to learn a trade. 
Clement (age 21), the eldest of seven children, was raised in Nsuaem. He helped his father on his cocoa farm at weekends. He entered secondary school but dropped out before the final year. His parents were unhappy with his decision to leave school and learn a trade (they had wanted their son to go to nursing or teachers' training college) but gave him a proportion of the family cocoa farm to harvest and prepare for sale to finance his masonry apprenticeship in Kumasi. Clement planned to have a cocoa farm alongside his trade, either through a lease or as a caretaker. If he could save enough, he would buy land to start his own farm. But he would not want his children to be cocoa farmers. He would prefer them to pursue a high level of education and get a good job. His children would have the legacy of his farm, and could always hire someone to take care of it.

activity of cocoa farming, and the identity of 'cocoa farmer', was one to which they did not want to lay claim. It should be noted that Kwaku, Owusu and Alex had acquired farming skills early and further had family-owned land on which they could independently work as adults. This fact meant that though it was not their preferred option, cocoa farming was an incomegenerating avenue they could fall back on.

Mosi, by contrast, while also having ambitions of learning a trade, did not hesitate to identify himself as a farmer. His perspective of cocoa farming was more positive - he saw it as a legitimate step up to something different and better. One reason might be because, unlike the others, he did not have formal schooling and therefore had not developed the self-image of 'student' as an oppositional identity to 'farmer'. It may also be that, as a migrant from the north, a group who have historically been hired labourers, owning a cocoa farm (whether one owned the land or worked on leased land) was a valid aspiration. Working first as a hired hand, then a caretaker and then a farm owner was part of his perceived upward trajectory towards his goal of learning a trade.

And what would be the place of cocoa farming in the lives of young men such as Mosi, Kwaku, Owusu and Alex, if they did attain their goal? Half of the young people who perceived farming as an investment into a preferred primary occupation said that they would prefer to leave farming behind completely. These were young people who had neither significant farming experience nor significant ties to the land and, presumably, have no easy access to land or an established cocoa farm. Thus, their 'preferences' could reflect an acceptance of the reality of their situation. The other half expected to engage in cocoa production as an additional source of income. These young people were those who had significant prior experience of cocoa farming and expected to have access to farmland (usually on their family's land). The story of Clement in Nsuaem in the Western Region illustrates the latter category (see box).

It is important to make the distinction between cocoa farming and ownership of a cocoa farm in Clement's story. His ambitions to go to school had been achieved through income from cocoa farming. His return to farming cocoa was a contingency plan, in order to invest in his aspirations of learning a trade. After becoming a mason, his ideal future involvement in cocoa would be as a farm owner, not as a farmer himself. In a similar vein, he would want his children to own his cocoa farms but not work on them. What Clement had in common with Kwaku, Owusu, Alex and Mosi was his valuing of the cocoa farming as a means of capital accumulation and as future investment, rather than an occupation.

\subsection{Formal work as a primary occupation, with no direct engagement with cocoa farming}

The young people in our focus group strongly indicated that the 'best' form of occupation was formal, salaried work, preferably in a whitecollar job. However, only a minority of young people considered this a realistic aspiration; these were predominantly full-time students in primary, junior high and senior high school who hoped to continue their education to the secondary or tertiary level. This group best illustrates the influence of educational attainment and educational aspirations on young people's expectations. Formal education can offer knowledge and skills to young people that potentially allow them to engage in a range of occupations, the final choice of which depends on a number of contextual and personal factors.

There were two extremes in the role of cocoa farming in the imagined futures of young people 
Charles (age 20) was born in Kumasi but 'since my parents work in the village, they brought me to the village'. After taking his junior high school examinations in Accra and while waiting for admission to secondary school, he returned to Aku-Nkwanta to help his parents with their farm. His parents said that the money he made from harvesting cocoa would be used to pay his tuition and buy school supplies. He was categorical that he was not interested in farming as an occupation because 'farming is tiring, and does not pay well', although he wanted to do agriculture in secondary school so that, in the future, he would work with the government. However, his father discouraged him: 'He tells me [agriculture] is a foolish course'. Charles would like to live in Accra with his family. And his parents' cocoa farm? 'We will give it as a gift to the poor people here.'

Ben (age 17) helped his parents with their food crop farm from a young age. On completing junior high school his father did not have money to send him to senior high school. His father would harvest the cocoa at the end of the year so he could save money towards Ben's school. Ben wanted to be an engineer, living anywhere but in Bedomase because he thought life was too hard in his town. If he had the means, he would make sure his parents did not have to grow cocoa. If eventually his parents were to bequeath the farm to him, he would find a caretaker for it.

who expected to reach higher levels of education. Most gave no space to direct involvement in farming; at best, they would find caretakers for their parents' farms but would not attempt to establish a farm on their own. This is because they believed they would not need farming since formal employment would provide them sufficient income and also because it would be incompatible with their lifestyle and status. Charles in Aku-Nkwanta in the Western Region and Ben in Bedomase in the Ashanti Region, both children of cocoa farmers, are representative of this group.

Another grouping of young people aspiring to white-collar work spoke about their willingness to do capital-intensive, large-scale commercial cocoa farming where they would employ others as workers. Generally, these were young people

Kwaku (age 23). At 15, with an absentee father and ten siblings, Kwaku quit school and took up farming. At first he did not know much about cocoa farming and did not make much money from it. He turned to charcoal-making, which he thought would bring him money faster. Three years previously, he returned to Moffram to find his mother struggling to maintain the cocoa farm. 'Looking at my situation - the fact that I didn't go to school I have no choice but to put everything into farming,' he said. He farmed with his mother on two acres of family land his maternal grandfather purchased. In addition, he had bought a piece of land in Nsawam, in the Eastern Region. Kwaku still wanted a chance to travel to a bigger town in the region to learn a trade but he wanted to make sure that he had cultivated the cocoa farm to the stage that he could comfortably leave it in someone's care. Even with a trade, he would still maintain a farm: 'I would know that I can come here, and get enough out of the cocoa to get myself out of that situation.' Kwaku would like to send his children to school. He hoped they would become teachers, but would help them to set up cocoa farms alongside whatever jobs they would do.

Richard (age 18). As a young boy, Richard remembers his mother carving out a small part of her farm for him and teaching him how to weed and sow it. At 18, and unlike many of his 'age-mates' in his town, he had his own cocoa farm. While Richard was in school, his older brother Kwaku took care of his farm. Although Richard made some profit from his cocoa farm that went towards his school fees, he made up his mind that he was not going to continue with cocoa farming. He considered it too much of a burden to expect his brother to look after three farms. Besides, they did not have enough money for inputs such as fertiliser and pesticides. When he was younger, Richard had wanted to be a cocoa farmer, but farming was no longer in his future plans; he was doing well at school and would rather become a teacher or a policeman. 
living in the relatively bigger towns of Wiamoase in the Ashanti Region and Asene in the Eastern Region where they had examples of wealthy and socially well-placed cocoa farmers. They were in junior and senior high school and had the expectation of going on to tertiary education and formal employment. They expected their formal jobs to provide access to capital for such a venture, either through their incomes or through better access to loan facilities. However, they considered this picture of large-scale farming a possibility only under the right conditions, notably the availability of lands, loans and supportive government policies and services.

\section{Education and aspirations}

From the foregoing discussion, the young people in our study ranked cocoa farming at the bottom of their aspirations, followed by trade. The perceived importance of cocoa farming diminished with actual or expected educational attainment. For those without formal schooling, cocoa farming was a step up towards a hoped-for better life; however, for those with some education, cocoa farming was a fall-back when one was unable to acquire sufficient education to aspire to another occupation. Kwaku and Richard, two brothers in Moffram in the Eastern Region, illustrate how education mediates the content of aspirations (see box). Unable to acquire the level of education he wanted, Kwaku had had to modify his aspirations to include cocoa farming, which he had previously shunned. Hoping to learn a trade, he wanted to use cocoa farming as a stepping stone but also as a backup plan if his aspiration did not work out. By contrast, his younger brother Richard had wanted to be a farmer when he was young. $\mathrm{He}$ was fortunate enough to do well in school and expected to move on to senior high school. Farming had no place in his future plans.

The distribution of young people across the three categories of aspirations also raises the question of what young people perceive as lying within the realm of possibility. Previous studies have suggested that young people can be unrealistic in their expectations (Leavy and Smith 2010). We found in our study that generally young people demonstrated an appreciation of what was possible for them in their context. The numbers of young people who aspired to undertake either full-time farming or salaried employment were low, compared to a majority aspiring to learn and practice a trade. Thus, while our sample of young people stated white-collar work to be the most desirable form of work, many of them were aware that this was out of reach to them, since it demanded more formal education, skills and knowledge than they expected to attain. If there was any area in which the young people in our sample were unrealistic, it was perhaps in the undue weight they placed on education as almost guaranteeing an occupation away from farming and, preferably, away from the rural sites of cocoa farming.

Again, young people's preference for farm ownership over farming as a primary occupation may be another indication that they have a fairly accurate reading of their environment; for instance, given that there is less land now for expanding cocoa production it may be that the future of cocoa farming is about acquiring farms from others or maintaining existing farms, or even working as a caretaker in order to acquire access to or ownership of existing farms.

\section{Young people's perception of cocoa farming}

The study also uncovered reasons for the ways in which young people configured cocoa farming in their future aspirations. The young people described the sheer drudgery of cocoa farming; the physical effort and time that is not compensated for by the profits from cocoa. Here, young people were making an observation about productivity and low incomes that are echoed in Ghana's policy documents, as we have discussed. This appears to bear out policy prescriptions about raising productivity and income from farming as a way of attracting younger people. What these policies overlook is the question of status. Embedded in young people's aspirations was a perceived hierarchy of work within which an occupation requiring manual labour ranked lower than formal or salaried work. As noted, other studies have found that young people reject agriculture not only for economic reasons but for social reasons such as status and prestige (see, for example, Perry 2009; Juma 2007). The idea that status is important to young people helps to solve the seeming paradox of youth with aspirations for formal work stating a possible interest in farming. This can be explained by their expectation that their social status would be based on the primary occupation, say as an accountant, lawyer, civil servant; they would not have the occupation label of 'farmer' since they would not personally 
undertake on-farm work but would hire labour or caretakers for the farms they owned.

When asked what it might take for them to consider farming, overall the young people we interviewed stated that the government would have to once more invest in cocoa in terms of new technologies and inputs (such as fertiliser and other chemicals). They also said that credit must be made readily available and accessible to farmers; remunerative prices must be paid for cocoa purchases; and that infrastructure and amenities should be available to make the rural areas more 'liveable'. Public investments in cocoa production would also raise the status of cocoa farming, since government's attention to farmers would signal to them and to the rest of the nation that cocoa farmers mattered. This need for recognition was especially strongly articulated in smaller cocoa-producing areas, where there was a stronger feeling of isolation and neglect.

Young people's general disinclination to farm is in consonance with their parents' stated aspirations for their children (Barrientos et al. 2007). Charles (from Subreho), whose father had told him not to do agriculture in school, shared his parents' disdain for farming and for the farming settlement in which they lived. Ben, a student in Bedomase, aspired to finish high school and live in a bigger town or city. He was not interested in farming but stated that he would endeavour to keep his parents' cocoa farm in the family. His perspective reflected his parents' more positive attitude to cocoa farming as the best available means of financing their child's education. Adult farmers were encouraging of their children owning cocoa farms but preferred the younger generation to find alternatives to cocoa farming as an occupation (ibid.). In this sense, young people's perception of the value of cocoa farming is similar to that of their parents. This continuity across generations questions the idea in policy narratives that it is the attitude of young people that is the obstacle to agricultural sustainability.

\section{Implications for policy}

This article offers insight into the particular context of cocoa production in rural Ghana and suggests that young people have a more complicated relationship with agriculture than the literature would suggest. First, contrary to the policy narrative that young people disdain farming in rural areas, the majority of young people in our sample appreciated that their education and other opportunities came to them because of their families' involvement with cocoa farming. Moreover, some young people returned to cocoa farming when in need of money or employment. Second, research shows that the different backgrounds and experiences of farming informed the role young people gave to farming in their long-term goals and current strategies. Third, while farming was not a preferred occupation, farm ownership was generally seen in a positive light.

Our findings on young people's engagement with and aspirations in Ghana's cocoa sector has implications for agricultural policy, policies for the wellbeing of young people, and the ways policy frames the relationship between young people and agriculture.

Policy attempts to involve young people more deeply in agriculture production must be based on an understanding of the economic and social significance of a particular crop, and of the ways in which policy and people have engaged with that crop historically. Thus, we would expect young people's perceptions of a relatively newer export crop, such as pineapple, to also be informed by the way it was introduced and supported by the government, and the sites and means of its production, as well as by the fact that the market for pineapple is more volatile than for cocoa (see Anyidoho 2009).

Policy attempts to involve young people in agriculture tend to focus on on-farm activities. Young people expressed interest in farming as a secondary activity and a commercial venture, and a preference for farm ownership. Of course, there is not always a strong correlation between what people think they will do in a situation, and what they might actually do. Nonetheless, these statements suggest that there are prospects for encouraging their involvement if policy goes beyond the usual approach to the young peopleagriculture nexus with its focus on young people's personal and direct involvement in farming. On a related note, policies on young people and agri-food should recognise opportunities for young people beyond primary production. Against a backdrop of rising urbanisation in SSA, increasingly stringent standards in agri-food chains, increased trade, 
and the likely emergence of larger-scale formal enterprises, there will be more employment opportunities throughout the agri-food sector, not just in primary production but also processing, catering and retail. These will not only be in rural areas but also in urban centres. Young people need the right skills to participate in the sector broadly defined, and policy should reflect and support this.

An important question is whether or not policies for the wellbeing of young people and policies for modernising and sustaining agriculture practically differ? In particular, the policies that prescribe the participation of young people in agriculture may be good for agriculture but are they good for the wellbeing of young people in rural areas? Policies should recognise and seek to resolve this tension, rather than seeking to constrain young people's attempts at physical and social mobility. Acknowledging that the agricultural value chain consists of more than on-farm work, and the probability that the manufacturing and retailing sides of the agrifood sector will become increasingly important in coming years, will simultaneously address the issue of sustaining agriculture while giving young people room to follow their aspirations.

The most important implication of our study is the need to recognise different categories of young people in agricultural policy formulation. Such policy would acknowledge that young people have different forms of preferred

\section{Notes}

1 Although there is a lack of current and accurate demographic statistics, one study indicates that the majority of Ghanaian farmers are over 50 years of age (Dankwa 2002, cited in Bosompem et al. 2010).

2 The total contribution of the 'non-traditional export crops' to total agricultural output fell from 18 to 10 per cent 2000-10 (MoFA 2011).

3 Despite the pressures on traditional land tenure systems due to migration, commercialisation, formalisation, and the imposition of statutory interactions with agriculture. Failure to take account of the heterogeneity of young people, even those residing in agricultural areas, might mean that we continue to overlook certain categories of young people. Many of the agricultural training/capacity development programmes target more educated youth - those with high school or tertiary education - because they are assumed to adopt innovative farming techniques and are more productive (see Barrientos et al. 2007). However, programmes to attract young people to agriculture need to also be tailored for young people who might be less educated or who are out of school, but who are sometimes more motivated and willing to do (and perhaps stay in) agriculture, given the right opportunities and incentives.

There is also a more normative rationale for making sure that young people do not slip through the gaps. When young people are not in school or in the formal sector labour force - that is, when they operate outside of certain structures - it is more difficult to reach them with social protection or with training and other opportunities. This is an important line of argument given emerging evidence suggesting that young people have been more vulnerable to the effects of the recent economic crisis (see Hossain and McGregor 2011), and are in danger of falling outside of social and policy structures and becoming even more marginalised. The development of properly targeted interventions is therefore key, as is their timeliness.

policy, about 80 per cent of land in Ghana continues to be reposed in the custody of customary institutions (ISSER 2005).

4 This is a system where groups of farmers selforganise to provide reciprocal labour.

5 However, cocoa production is perhaps less vulnerable to labour shortages than other crops because of sharecrop arrangements (Christine Okali, pers. comm. 22 December 2011).

6 The published report is available: Barrientos et al. (2007). 


\section{References}

Anyidoho, N.A. (2009) Migrant Workers in Export

Production: Comparing Aspirations and Realities in the Pineapple and Cocoa Sections of Ghana, research report produced under the Migration DRC, Brighton: IDS

Anyidoho, N.; Kayuni, H.; Ndungu, J.; Sall, M. and Tadele, G. (2011) 'Policy Narratives around Young People and Youth', unpublished paper prepared for FAC Young People and Agriculture theme of the Future Agricultures Consortium, www.future-agricultures.org (accessed 3 August 2012)

Asuming-Brempong, S.; Sarpong, D.; Amoo, P. and Asenso-Okyere, K. (2007) Cocoa Child Labour Study in Ghana, Accra, Ghana: Ministry of Manpower, Youth and Employment (MMYE)

Barrientos, S.; Asenso-Okyere, K.; AsumingBrempong, S.; Sarpong, D.; Anyidoho, N.A.; Kaplinsky, R. and Leavy, J. (2007) Mapping Sustainable Production in Ghanaian Cocoa, London, http://collaboration.cadbury.com/ ourresponsibilities/cadburycocoapartnership/ Pages/mappingsustableproduction.aspx (accessed 3 August 2012)

Bosompem, M.; Ntifo-Siaw, E. and Kwarteng, J.A. (2010) 'Is Precision Agriculture Feasible in Cocoa Production in Ghana?: The Case of "Cocoa High Technology Programme" in the Eastern Region of Ghana', Proceedings of the 10th International Conference on Precision Agriculture, ICPA, Hyatt Regency Tech Center in Denver, Colorado, USA, 18-21 July

Dankwa, J.B. (2002) 'Factors Affecting the Adoption Levels of Cocoa Technologies in the Ashanti Region of Ghana', unpublished master's thesis, Department of Agricultural Economics and Extension, University of Cape Coast, Ghana

Del Franco, N. (2006) 'Negotiating Adolescence in Rural Bangladesh: A Journey through School, Love and Marriage', unpublished DPhil thesis, University of Sussex

Hashim, I.M. (2005) Research Report on Children's Independent Migration from Northeastern to Central Ghana, research report for the Development Research Centre on Migration Globalisation and Poverty, www.migrationdrc.org (accessed 4 August 2012)

Hill, P. (1963) The Migrant Cocoa Farmer of Southern Ghana: A Study of Rural Capitalism, London: Cambridge University Press

Hossain, N. and McGregor, J.A. (2011) 'A "Lost Generation"? Impacts of Complex Compound
Crises on Children and Young People', Development Policy Review 29.5: 565-84

ILO (2010) Global Employment Trends, Geneva: International Labour Organization

ISSER (2005) Report on Land Tenure and Land Policy Research Survey, July, Accra, Ghana: Institute for Statistical, Social and Economic Research Juma, A. (2007) Promoting Livelihood Opportunities for Rural Youth: Some Lessons from Tanzania, paper for IFAD Governing Council Roundtable 'Generating Remunerative Livelihood Opportunities for Rural Youth', Rome, February 2007

Kritzinger, A. (2002) 'Rural Youth and Risk Society: Future Perceptions and Life Chances of Teenage Girls on South African Farms', Youth and Society 33.4: 545-72

Leavy, J. and Smith, S. (2010) Future Farmers: Youth Aspirations, Expectations and Life Choices, Discussion Paper 013, Future Agricultures Consortium

MacBrayne, P. (1987) 'Educational and Occupational Aspirations of Rural Youth: A Review of the Literature', Research in Rural Education 4.3: 135-41

Mba, C. (2004) 'Population Ageing and Poverty in Rural Ghana', paper presented at the Union for African Population Science African Conference on Ageing, Johannesburg, South Africa, 18-20 August 2004

Mikell, G. (1989) Cocoa and Chaos, New York: Paragon House Publishers

MoFA (2011) Facts and Figures (2010), Report produced by the Statistics, Research and Information Directorate (SRID) of the Ministry of Food and Agriculture [MoFA], Accra, Ghana

MoFA (2007) Food and Agriculture Sector Development Policy - FASDEP II, Accra: Ministry of Food and Agriculture

MMYE (n.d.) National Employment Policy (Final Draft Version 4), Accra, Ghana: Ministry of Manpower, Youth and Employment

Morrison Gutman, L. and Akerman, R. (2008) Determinants of Aspirations, Research Report 27, London: Centre for Research on the Wider Benefits of Learning, Institute of Education

MYS (2010) The National Youth Policy, Accra, Ghana: Ministry of Youth and Sports

NDPG (2010) The Ghana Shared Growth and Development Agenda 2010-2013, Vol 1 - Policy Framework (Final Draft), Accra, Ghana: National Development Planning Commission 
NDPG (2005) The Ghana Growth and Poverty Reduction Strategy, 2006-2009, Accra, Ghana: National Development Planning Commission Nukunya, G.K. (1992) Tradition and Change in Ghana: An Introduction to Sociology, Accra, Ghana: Ghana Universities Press

Perry, D. (2009) 'Fathers, Sons and the State: Discipline and Punishment in a Wolof Hinterland', Cultural Anthropology 24.1: 33-67

Quaglia, R.J. and Cobb, C.D. (1996) 'Toward a Theory of Student Aspirations', Journal of Research in Rural Education 12.3: 127-32

Stloukal, L. (2000) What can Agricultural Censuses tell us about Rural Population Ageing in Developing Countries?, FAO, www.fao.org/sd/WPdirect/ WPan0051.htm (accessed 13 August 2011)
Sumberg, J. and Okali, C. (2006) 'Tomatoes, Decentralization, and Environmental Management in Brong Ahafo, Ghana', Society and Natural Resources 19.1: 19-31

Whitehead, A.; Hashim, I. and Iversen, V. (2007) Child Migration, Child Agency and Intergenerational Relations in Africa and Asia, Working Paper T24, University of Sussex: Development Research Centre on Migration, Globalisation and Poverty

World Bank (2006) World Development Report 2007: Development and the Next Generation, Washington DC: World Bank 